\title{
Alternative conifer release treatments affect below- and near-ground microclimate
}

\author{
by Phillip E. Reynolds ${ }^{1}$, James A. Simpson ${ }^{2}$, R.A. Lautenschlager ${ }^{3}$, F. Wayne Bell ${ }^{3}$, Andrew \\ M. Gordon ${ }^{2}$, Donald A. Buckley ${ }^{1}$ and Donald A. Gresch ${ }^{2}$
}

Li-Cor weather stations and thermistor/resistance soil cells were used during 1994 to monitor microclimate in young spruce plantations during the first growing season after the following replicated alternative conifer release treatments [brush saw, Silvana Selective, Release ${ }^{\circledR}$ (a.i., triclopyr) herbicide, Vision ${ }^{\circledR}$ (a.i., glyphosate) herbicide], and control (no treatment) were applied. Treatments were conducted in mid-August (herbicides) and late October and early November (cutting) 1993. In 1994, temperature, photosynthetically-active radiation (PAR), and relative humidity $(\mathrm{RH})$ were monitored near $(0.25 \mathrm{~m})$ and above $(2 \mathrm{~m})$ the forest floor. Fiberglass thermistor/resistance soils cells were installed 15 and $30 \mathrm{~cm}$ deep, and soil moisture and temperature were read bimonthly. In relation to controls, PAR near and above the forest floor increased on all conifer release treatments. By July, PAR near the forest floor declined on both the cut and herbicide treatments. That decline occurred in early July for the brush saw treatment, but in late July for the Vision ${ }^{\circledR}$ treatment. $\mathrm{PAR}$ at $2 \mathrm{~m}$ was similar among conifer release alternatives and significantly greater than for controls throughout the growing season. Increased solar radiation resulted in significant soil warming following the conifer release treatments. During the growing season, duff $(5 \mathrm{~cm})$ and mineral $(15 \mathrm{~cm})$ soil temperatures were highest for the Vision ${ }^{\circledR}$ and Release ${ }^{\circledR}$ treatments, and lower on the brush saw and control treatments. November soil temperatures were slightly cooler in released than control plots. Frequent rains resulted in relatively high $\mathrm{RH}$ and soil moisture readings during the 1994 growing season. Relative humidity near the forest floor was lowest for the Vision ${ }^{8}$, intermediate for the brush saw, and highest for the control treatments. During the growing season after treatments, soil moisture levels were higher on treated than control plots.

Key words: microclimate, alternative conifer release treatments, Fallingsnow Ecosystem Project, photosynthetically-active radiation (PAR), soil temperature and moisture, relative humidity, ecosystem study
Des stations météorologiques Il-Cor ainsi que des cellules sensibles à la chaleur transmise dans le sol ont été utilisées en 1994 pour étudier le microclimat de jeunes plantations d'épinette au cours de la première saison de croissance suite à l'application de traitements alternatifs répétés de dégagement des coniferes (scie débroussailleuse, Silvana Selective, phytocide Release ${ }^{\circledR}$ [é.a., triclopyr], et phytocide Vision $^{\circledR}$ [é.a., glyphosate], accompagnés d'un témoin (aucun traitement). Les traitement ont été effectués à la mi-août (phytocides) et à la fin octobre et début novembre (coupe) 1993. En 1994, la température, le rayonnement photosynthétiquement utilisable (RPU) et l'humidité relative (HR) ont été mesurés près $(0.25 \mathrm{~m})$ et au-dessus $(2 \mathrm{~m})$ du parterre forestier. Des cellules sensibles à transmission de la chaleur en fibres de verre furent installées à 15 et $30 \mathrm{~cm}$ de profondeur, et l'humidité et la température du sol furent relevées deux fois par mois. Par rapport aux témoins, le RPU près et au-dessus du parterre forestier a augmenté pour tous les traitements de dégagement des coniferes. En juillet, le RPU près du parterre avait diminué autant pour les traitements de coupe que pour les phytocides. Cette réduction s'est produite au début juillet pour le traitement à la scie débroussailleuse, mais à la fin juillet pour le traitement au Vision ${ }^{\otimes}$. Le RPU à 2 m était le même pour tous les traitements de dégagement des conifères et significativement plus élevé que les témoins tout au long de la saison de croissance. L'augmentation de la rayonnement solaire a entrainé un réchauffement significatif du sol, conséquence des traitements de dégagement des conifères. Au cours de la saison de croissance, la température de la litière (5 $\mathrm{cm})$ et du sol minéral $(15 \mathrm{~cm})$ ont été les plus élevées suite aux traitement au Vision ${ }^{\circledR}$ et Release ${ }^{\circledR}$, et les plus faibles suite aux traitements de coupe et pour les témoins. La température du sol en novembre étaient légèrement plus faibles dans les parcelles traitées que dans les parcelles témoins. Les pluies fréquentes ont entraîné une hausse relative de HR et des lectures d'humidité du sol au cours de la saison de croissance de 1994. L'humidité relative à proximité du parterre forestier était la plus faible suite aux traitements au Vision ${ }^{8}$, intermédiaire pour les traitements de coupe, et plus élevée pour les parcelles témoins. Au cours de la saison de croissance qui a suivi les traitements, le niveau d'humidité du sol était plus élevé dans les parcelles traitées que dans les parcelles témoins.

Mots clés: microclimat, traitements alternatifs de dégagement des conifëres, projet écosystémique de Fallingsnow, rayonnement photosynthétiquement utilisable (RPU), température et humidité du sol, humidité relative, étude écosystémique

\section{Introduction}

Below- and near-ground microclimate is affected by the amount of vegetation that is present on a forest site. Changes in light, temperature, relative humidity and moisture produced by different vegetation management practices, including different conifer release practices, affect plant succession (Van Cleve et al. 1993 a,b; Vitousek and Reiners 1975) habitat quality

\footnotetext{
${ }^{1}$ Canadian Forest Service-Sault Ste. Marie, P.O. Box 490, 1219 Queen St. East, Sault Ste. Marie, Ontario, Canada P6A 5M7.

${ }^{2}$ Department of Environmental Biology, University of Guelph, Guelph, Ontario, Canada N1G 2W1.

${ }^{3}$ Ontario Forest Research Institute, P.O. Box 969, 1235 Queen St. East, Sault Ste. Marie, Ontario, Canada P6A 5N5.
}

(Lautenschlager 1993), and microsite suitability for crop production. Temporary removal of vegetation increases solar radiation reaching the forest floor, results in soil warming (Brand and Janas 1988; Wood and Von Alten 1993), and raises soil moisture levels because of reduced site evapotranspiration (Bosch and Hewlett 1982; Kochenderfer and Wendel 1983; Stone 1973). Increased soil moisture (Burger and Pritchett 1984; Matson and Vitousek 1981; Stanford and Epstein 1974) coupled with soil warming (Powers 1990) produces conditions favourable for nutrient turnover ( $\mathrm{N}$ and $\mathrm{C}$ mineralization), and improved soil moisture enhances nutrient uptake (Nambiar and Sands 1993). Improved moisture and nutrient status combined with increased light, generally results in increased photosynthesis 
(Eastman and Camm 1995; Lieffers et al. 1993) and ultimately, improved crop survival and growth (Newton et al. 1992; Radosevich and Osteryoung 1987).

Microclimatic changes may produce habitats which are more or less favourable for associated macro- (moose, deer, mice, etc.) and microorganisms (bacteria, ectomycorhizae, etc.) (Harvey et al. 1986; Lautenschlager 1993; Ruehle 1982; Vare 1989). For example, increased soil moisture and nearground humidity may favour earthworms, gastropods, amphibians and shrews. Microclimate changes also are expected to profoundly affect plant establishment, composition, growth and structure (habitat).

Microclimatic, habitat, and associated population changes have not been specifically documented or quantified for alternative conifer release treatments in the boreal mixedwood forest type. Karakatsoulis et al. (1989) reported on changes in photosynthetically-active radiation (PAR), air, and soil temperatures after manual (hand cutting) and chemical [Vision ${ }^{\circledR}$ (a.i., glyphosate)] release of douglas fir [Pseudotsuga menziesii (Mirb.) Franco] seedlings. Release ${ }^{8}$ treatments are commonly conducted on conifer plantations throughout North America (Walstad and Kuch 1987). This study documents below- and near-ground microclimatic changes associated with several alternative conifer release treatments in the boreal mixedwood forest type (i.e., two brush cutting methods, two herbicides, and untreated control), and provides a data base which should contribute to our understanding of plant and animal changes associated with these treatments. Specific objectives were to provide data for interpreting (1) abiotic processes and interactions (e.g., nutrient leaching) (Simpson et al. 1997), (2) biotic processes and interactions (e.g., physiological response of seedlings to treatments), and (3) population changes being studied by other cooperators participating in the Fallingsnow Ecosystem Project (Hawkins et al. 1997; Lautenschlager et al. 1997 a,b; Woodcock et al. 1997)

\section{Methods}

Site Description and History, Experimental Design, and Vegetation Management Treatments

The Fallingsnow Ecosystem Project $\left(48^{\circ} 8-13^{\prime} \mathrm{N}, 89^{\circ}\right.$ $49-53^{\prime} \mathrm{W}$ ) is about $60 \mathrm{~km}$ southwest of Thunder Bay, Ontario in Fraleigh Township (Bell et al. 1997a), and is part of the Great Lakes-St. Lawrence forest region (Rowe 1972). The study used a randomized complete block design, with four blocks (each 28 to $52 \mathrm{ha}$ ) and the following conifer release treatments: (1) motor-manual release with brush saws (mid-late October 1993), (2) mechanical release with the Silvana Selective/Ford Versatile (late October-early November 1993) (Bell et al. 1997b; Mitchell and St-Amour 1995), (3) helicopter (BELL 206) applied Release $^{\circledR}$ (triclopyr $-1.9 \mathrm{~kg}$ a.e. $\mathrm{ha}^{-1}$ ) herbicide (midAugust 1993), (4) helicopter applied Vision ${ }^{\circledR}$ (glyphosate - $1.5 \mathrm{~kg}$ a.e. ha ${ }^{-1}$ ) herbicide (mid-August 1993), and (5) control (no treatment). Each of the five treatments, located on each of the four blocks, ranged from 3 to 12 ha (Bell et al. 1997a). The various release treatments were designed to control overstory trembling aspen (Populus tremuloides Michx.) and other non-conifer species.

The blocks range in elevation from 380 to $550 \mathrm{~m}$ (Bell et al. 1997a,b). Soils are mostly silty clay loams. Drainage is variable, ranging from imperfectly drained to well drained (Simpson et al. 1997). In general, blocks one and three are wet and blocks two and four are drier. The blocks were harvested and planted with bareroot white spruce [Picea glauca (Moench) Voss] on blocks two, three and four and with black spruce [Picea mariana (Mill.) B.S.P.] on block one, three to eight years before the study began. The blocks were site prepared with Young's teeth or a power disc trencher prior to planting. Prior to harvesting, the stands consisted of aspen (30-100\%), balsam fir [Abies balsamea (L.) Mill.] (20-50\%), white spruce (0-20\%), and black spruce and white birch (Betula papyrifera Marsh.) (each 0-10\%). The pre-harvest stands ranged in age from 75 to 101 years and were $60-70 \%$ stocked, 21-23 m tall, and classified as site class two (block three) and three. At treatment, seedlings averaged $82 \mathrm{~cm}$ height compared with $2.6 \mathrm{~m}$ for major competitors. Seedling survival prior to treatment averaged $86 \%$ and stocking was at 1,700 spruce ha- ${ }^{-1}$. See Bell et al. (1997a,b) and Thompson et al. (1997) for additional information about the study area and treatments.

\section{Microclimate Measurements and Data Analysis}

Three $\mathrm{Li}$-Cor weather stations were installed on block three (420 m elev.) in early June 1994 next to pre-existing lysimeter locations (Simpson et al. 1997) in the control, brush saw, and Vision ${ }^{\circledR}$ treatment plots and were programmed to measure air and soil temperatures, relative humidity $(\mathrm{RH})$, and photosynthetically-active radiation (PAR) every 60 seconds and to record minimum, maximum, mean (temperature and $\mathrm{RH}$ ), and integrated (PAR) values hourly using $\mathrm{Li}-\mathrm{Cor} \mathrm{LI}-1000$ dataloggers. Two Li-Cor 1000-15 sensors (each station) were used to measure soil temperatures at 5 and $15 \mathrm{~cm}$ depth. Air (Li-Cor 1000-16 sensors), RH (Vaisala Hummitter and HMP-35A sensors), and PAR (Li-Cor LI-190SA quantum sensors) were measured near $(0.25 \mathrm{~m})$ the forest floor and at $2 \mathrm{~m}$ above the forest floor. PAR sensors were mounted on top of $\mathrm{Li}$-Cor instrument enclosure boxes or mounted $0.25 \mathrm{~m}$ above the forest floor. Air and RH (Hummitter) sensors $2 \mathrm{~m}$ above the forest floor were placed next to each other inside the instrument enclosure boxes. Air and RH (HMP-35A) sensors near the forest floor were housed in radiation shields placed in close proximity to the forest floor PAR sensor. The original Vaisala temperature sensor located in the HMP-35A sensor was replaced with a compatible Li-Cor temperature sensor. Daily rainfall and hourly windspeed were also recorded with a Geneq raingauge and with a Met One 014A wind speed sensor at the Vision ${ }^{\circledR}$ station only.

In addition, fiberglass thermister/resistance soil cells (ELE International, Soiltest Products Division, Lake Bluff, ILL) were installed at 15 and $30 \mathrm{~cm}$ at 25 locations block ${ }^{-1}$ (five treatment $\left.{ }^{-1}\right)$. Most cells were installed in early June, but cell installation in the Silvana Selective treatment was not completed until early August. A preliminary survey indicated that although rooting zones were not mutually exclusive, spruce seedling roots were generally shallow $(\sim 15 \mathrm{~cm})$, whereas aspen roots were normally deeper $(\sim 30+\mathrm{cm})$, and that roots were generally not observed below $45-50 \mathrm{~cm}$. Where feasible, soil cell locations corresponded with existing lysimeter installations (Simpson et al. 1997). Soil cells were located on all blocks and treatments, except the block one Silvana Selective treatment. Once installed, soil moisture and temperature were read bimonthly or concurrent with physiological measurements through November 1994. The soil cells were calibrated for soil conditions at the Fallingsnow research site. Following calibration, cell resistance data were converted to soil moisture data (\%) prior to statistical analysis. 
Daily means for temperatures and RH and sums for PAR (Li-Cor weather stations) were calculated and graphed (CSS Statistica software) for each treatment. ANOVAs were performed (CSS Statistica software) for Li-Cor-generated data subsets consisting of early (3-10 June) and late (12-15 August) summer, based upon daily measures of these parameters for each treatment (Meredith and Stehman 1991). Treatment differences less than or equal to $10 \%$ were considered significant. Treatment differences associated with soil temperatures and moisture levels (soil cells) were determined via routine ANOVA procedures for each sample date. In these analyses, each block was treated as a replicate. Transformations of data prior to analyses were not required to achieve normal data distributions or equal variances. Treatment means were compared by Tukey's Test at a $10 \%$ level of significance.

\section{Results}

\section{Photosynthetically-active Radiation (PAR)}

Total daily photosynthetically-active radiation $\left(\mathrm{mol} \mathrm{m}^{2} \cdot \mathrm{d}^{-1}\right)$ at $2 \mathrm{~m}$ above the forest floor (Fig. 1A) or near the forest floor (Fig. 1B) increased after all conifer release treatments. The increase at $2 \mathrm{~m}$ was significant, remaining so through August; but, no difference among release treatments was observed (Table 1). The increase near the forest floor $(\sim 0.25 \mathrm{~m})$ was also significant through August; however, by August, differences among release treatments were also evident (Table 1). Between late June and August, radiation near the forest floor declined for both brush saw and Vision ${ }^{\circledR}$ treatments, but the decline was more rapid for the brush saw treatment. Light reaching the forest floor was greatest for the Vision ${ }^{\circledR}$ treatment.

\section{Air Temperatures}

Mean daily air temperatures at $2 \mathrm{~m}$ above the forest floor fluctuated from 9 to $22^{\circ} \mathrm{C}$ during early summer (June) and from 9 to $20^{\circ} \mathrm{C}$ during late summer (August), with no difference among treatments in June or August. Similarly, mean daily temperatures near the forest floor fluctuated from 9 to $20^{\circ} \mathrm{C}$ during August but did not differ among treatments.

\section{Soil Temperatures}

Duff temperatures at $5 \mathrm{~cm}$ (Fig. $2 \mathrm{~A}$ ) differed among treatments in June, but not in August. Throughout the summer, duff temperatures remained highest for the Vision ${ }^{\circledR}$ treatment and were higher on this treatment than on the control treatment in June (Table 1). In June, duff temperatures also tended to be higher on the brush saw treatment than on the control treatment (Table 1). Mineral soil temperatures at $15 \mathrm{~cm}$ (Fig. 2B) also remained highest for the Vision ${ }^{\circledR}$ treatment throughout the summer, and differed from the control and brush saw treatments in June and in August (Table 1).
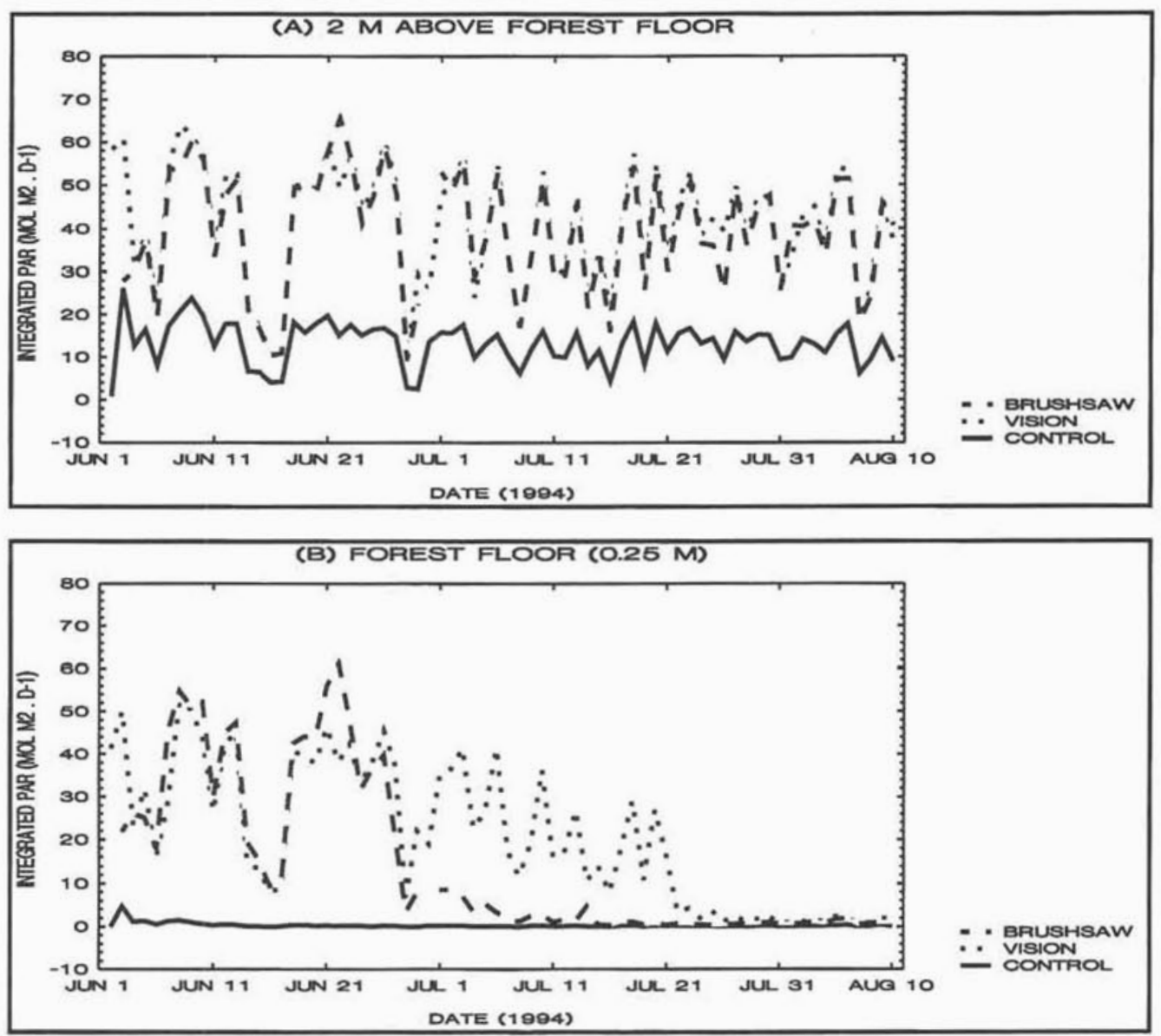

Fig. 1. Daily photosynthetically-active radiation (PAR mol $\left.\mathrm{m}^{2}\right)$ above $(2 \mathrm{~m})$ or near $(0.25 \mathrm{~m})$ the forest floor during the first growing season after alternative conifer release treatments. Data presented are from $\mathrm{Li}$-Cor weather stations. 
Table 1. Photosynthetically-active radiation (PAR), mean daily duff and mineral soil temperatures, and above- and near-ground relative humidity (RH) during early and late summer for the first post-treatment growing season following alternative conifer release treatments. Data [PAR (daily totals); temperatures and RH (daily means)] are from Li-Cor weather stations for 3-10 June and 12-15 August, 1994

\begin{tabular}{|c|c|c|c|c|c|c|c|c|c|c|}
\hline \multirow[b]{3}{*}{ Treatment } & \multicolumn{4}{|c|}{$\operatorname{PAR}\left(\mathrm{mol} \mathrm{m}^{2} \mathrm{~d}^{-1}\right)$} & \multicolumn{4}{|c|}{ Temperatures (C) } & \multicolumn{2}{|c|}{ RH (\%) } \\
\hline & \multicolumn{2}{|c|}{$\begin{array}{c}\text { Above-ground } \\
\text { at } 2.00 \mathrm{~m}\end{array}$} & \multicolumn{2}{|c|}{$\begin{array}{l}\text { Near-ground } \\
\text { at } 0.25 \mathrm{~m}\end{array}$} & \multicolumn{2}{|c|}{$\begin{array}{l}\text { Soil duff } \\
\text { at } \sim 5 \mathrm{~cm}\end{array}$} & \multicolumn{2}{|c|}{$\begin{array}{l}\text { Mineral soil } \\
\text { at } 15 \mathrm{~cm}\end{array}$} & \multirow{2}{*}{$\begin{array}{l}\begin{array}{c}\text { Above-ground } \\
\text { at } 2.00 \mathrm{~m}\end{array} \\
\text { August }\end{array}$} & \multirow{2}{*}{$\begin{array}{c}\begin{array}{c}\text { Near-ground } \\
\text { at } 0.25 \mathrm{~m}\end{array} \\
\text { August }\end{array}$} \\
\hline & June & August & June & August & June & August & June & August & & \\
\hline Control & $18.14 b^{1}$ & $0.19 b$ & $1.50 b$ & $0.22 c$ & $13.83 b$ & $14.52 a$ & $12.25 b$ & $14.10 b$ & $77.10 a$ & $88.11 a$ \\
\hline Brush saw & $45.55 a$ & $34.68 a$ & $40.22 a$ & $1.24 b$ & $14.69 a b$ & $14.28 a$ & $11.82 b$ & $13.74 b$ & $69.35 b$ & $83.74 a$ \\
\hline Vision $^{\otimes}$ & $48.83 a$ & $35.56 a$ & $39.36 a$ & $1.81 a$ & $15.42 a$ & $15.90 a$ & $13.02 a$ & $15.43 a$ & $72.2 a b$ & $78.68 b$ \\
\hline
\end{tabular}

${ }^{1}$ Numbers within columns followed by the same letter $(a-c)$ are not significantly different at the $10 \%$ level according to Tukey's test.
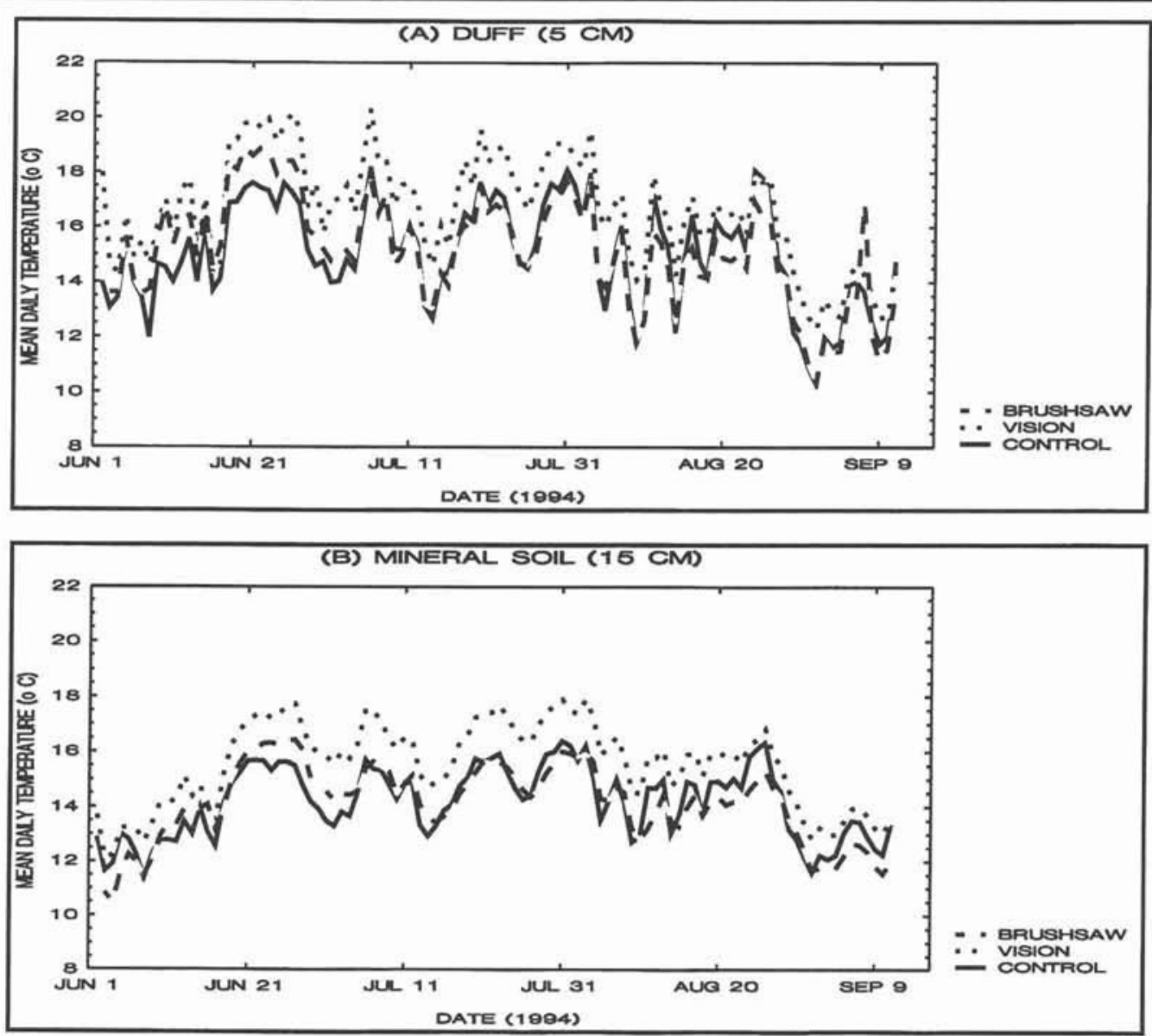

Fig. 2. Mean daily duff $(5 \mathrm{~cm})$ and mineral soil $(15 \mathrm{~cm})$ temperatures during the first growing season after alternative conifer release treatments. Data presented are from Li-Cor weather stations.

Soil cell data indicated that soil temperatures on all conifer release treatments (Fig. 3) were generally greater during the growing season than on controls. These temperatures differed (Table 2) from control temperatures on 28 July at $15 \mathrm{~cm}$ (Fig. 3A) and on 27 June and 28 July at $30 \mathrm{~cm}$ (Fig. 3B). Differences among release treatments were only observed at $30 \mathrm{~cm}$ on 28 July (Table 2). Mean soil temperatures peaked in late June and declined thereafter. By 5 October, soils at $15 \mathrm{~cm}$ were colder than those at $30 \mathrm{~cm}$. By 16 November, temperatures on the conifer release treatments were slightly cooler than those for controls.

\section{Relative Humidity}

Mean daily RH at $2 \mathrm{~m}$ above the forest floor (Fig. 4A) fluctuated around $80 \%$ throughout the summer. No treatment differences were observed in June. In August, $\mathrm{RH}$ for the brush saw treatment was lower than that for the control treatment (Table 1). Also, $\mathrm{RH}$ for the Vision ${ }^{\circledR}$ treatment tended to be lower than that for the control treatment. In August, mean daily RH near the forest floor (Fig. 4B) was higher than RH at $2 \mathrm{~m}$ above the forest floor for all treatments. RH near the forest floor was lowest for the Vision ${ }^{\circledR}$ treatment and highest for the control treatment. 

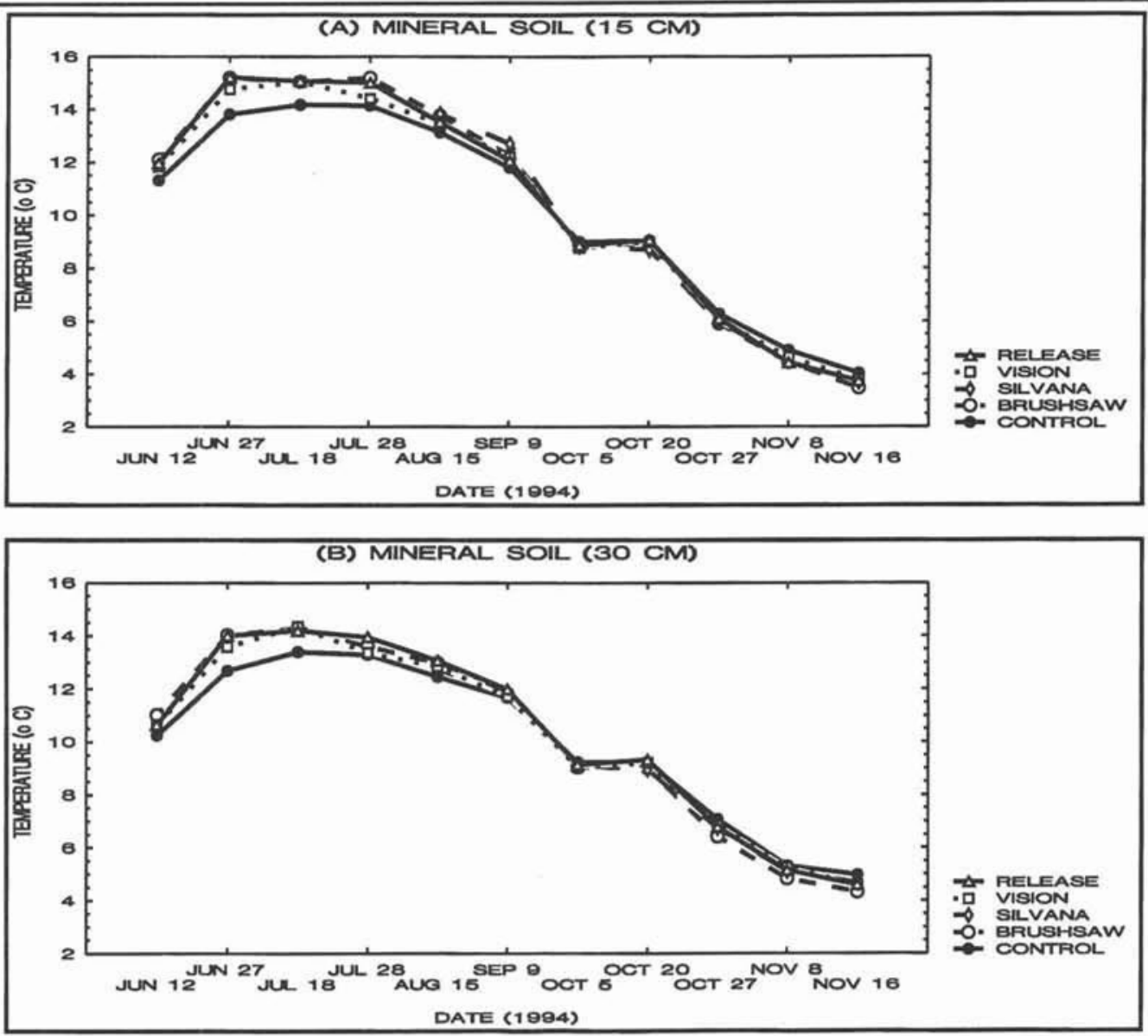

Fig. 3. Seasonal soil temperature differences at 15 and $30 \mathrm{~cm}$ depth during the first growing season after alternative conifer release treatments. Data presented were obtained from buried thermister/resistance soil cells (ELE International, Soiltest Products Division).

Table 2. Mean mineral soil temperatures and moisture levels during the first growing season after alternative conifer release treatments. Data presented were obtained from buried thermister/resistance soil cells (ELE International, Soiltest Products Division) for those measurement dates in 1994 where signifcant treatment differences occurred

\begin{tabular}{|c|c|c|c|c|c|c|c|c|}
\hline \multirow{3}{*}{ Treatment } & \multicolumn{3}{|c|}{ Mean mineral soil temperatures (C) } & \multicolumn{5}{|c|}{ Mean mineral soil moisture (\%) } \\
\hline & \multirow{2}{*}{$\frac{15 \mathrm{~cm}}{28 \mathrm{July}}$} & \multicolumn{2}{|c|}{$30 \mathrm{~cm}$} & \multicolumn{2}{|c|}{$15 \mathrm{~cm}$} & \multicolumn{3}{|c|}{$30 \mathrm{~cm}$} \\
\hline & & 27 June & 28 July & 9 September & 5 October & 15 August & 9 September & 5 October \\
\hline Control & $14.13 b^{1}$ & $12.68 b$ & $13.30 c$ & $20.48 b$ & $24.78 b$ & $24.46 b$ & $19.83 b$ & $21.69 b$ \\
\hline Brushsaw & $15.20 a$ & $14.02 a$ & $13.60 b$ & $25.40 a b$ & $29.38 a b$ & $34.45 a b$ & $28.97 a b$ & $29.76 a b$ \\
\hline Silvana & - & - & - & $29.17 a$ & $32.03 a b$ & $26.56 b$ & $28.19 a b$ & $29.36 a b$ \\
\hline Vision ${ }^{8}$ & $14.41 a b$ & $13.59 a$ & $13.36 b c$ & $26.56 a b$ & $29.05 a b$ & $32.62 a b$ & $30.47 a b$ & $31.58 a b$ \\
\hline Release & $15.01 a b$ & $14.00 a$ & $13.96 a$ & $28.17 a$ & $32.85 a$ & $41.54 a$ & $33.74 a$ & $36.55 a$ \\
\hline
\end{tabular}

${ }^{1}$ Numbers within columns followed by the same letter $(a-c)$ are not significantly different at the $10 \%$ level according to Tukey's test.

\section{Rainfall and Soil Moisture}

Cumulative precipitation was $335 \mathrm{~mm}$ from 1 June through 17 November 1994 occurring as frequent rains ranging from approximately 1 to $25 \mathrm{~mm}$ (Fig. 5). Most major rains occurred early in June and July.

Soil moisture levels (Fig. 6) were generally higher following the conifer release treatments. Moisture levels on some treated plots differed (Table 2) from control levels on 9 September and 5 October at $15 \mathrm{~cm}$ (Fig. 6A) and on 15 August, 9 September, and 5 October at $30 \mathrm{~cm}$ (Fig. 6B). Differences among release treatments were only observed at $30 \mathrm{~cm}$ depth on 15 August (Table 2). Soil moisture reached its lowest level on 9 September, and increased, in response to fall rains, thereafter. By 9 September, soils at $15 \mathrm{~cm}$ were wetter than those at $30 \mathrm{~cm}$.

\section{Discussion}

Conifer release alternatives reduced competing vegetation (Bell et al. 1997b), and improved microclimatic conditions for the young spruce trees. By August, however, regrowth of competing vegetation caused a decline in radiation on the forest floor on both brush saw and Vision ${ }^{\circledR}$ treatments, but this decline occurred sooner on the brush saw treatment. Vegetation cover (Bell et al. 1997a) varied by treatment type and influenced the degree of forest floor irradiation. One growing season post-treatment, combined cover for woody and nonwoody species was greatest on the control treatments, less (intermediate) on the brush saw treatments, and least on Vision ${ }^{\mathbb{B}}$ treatments. Consequently, forest floor measurements of PAR beneath brush saw canopies in early August did not differ from 

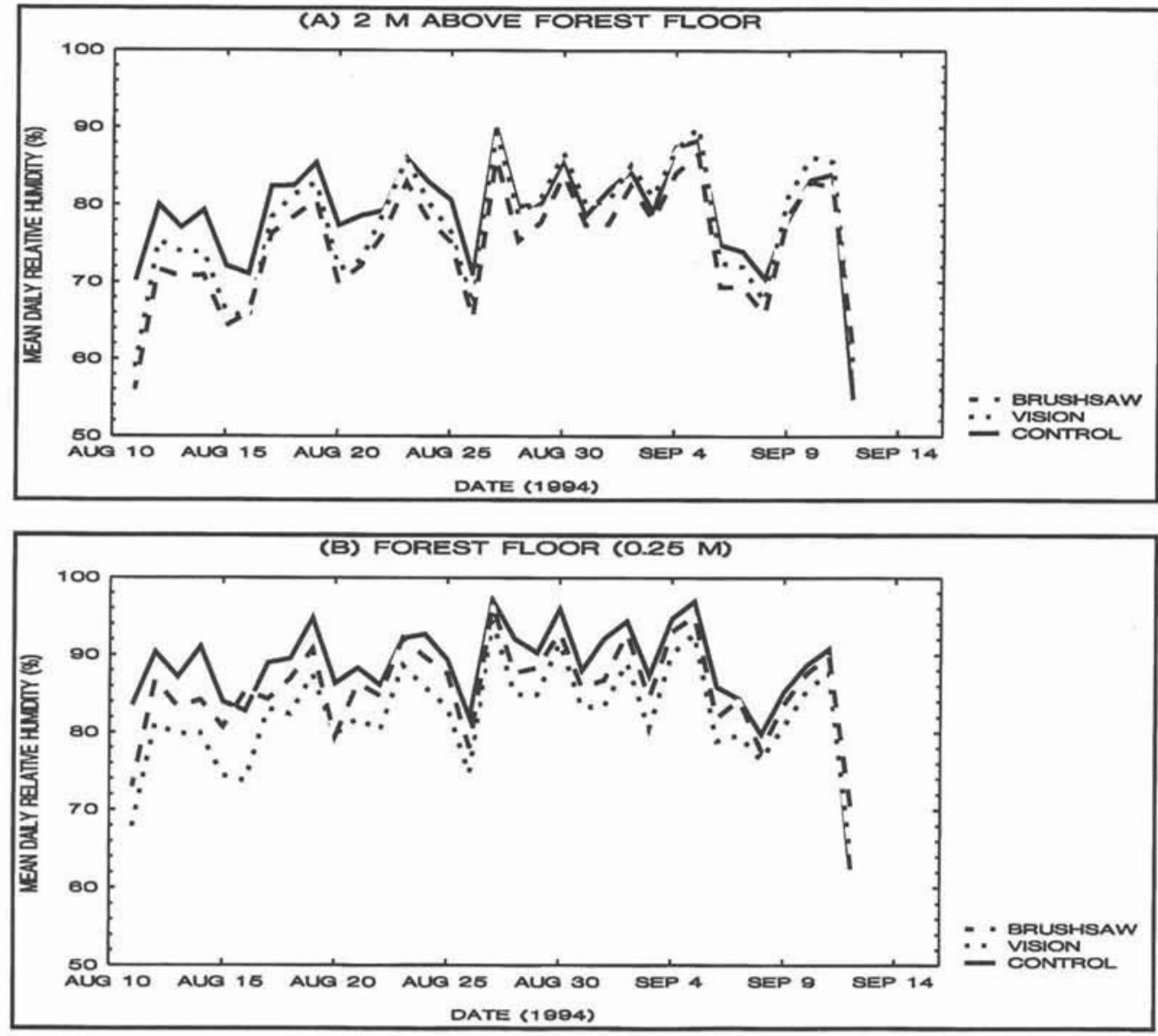

Fig. 4. Mean daily relative humidity $(\mathrm{RH})$ above $(2 \mathrm{~m})$ or near $(0.25 \mathrm{~m})$ the forest floor during the first growing season after alternative conifer release treatments. Data presented are from Li-Cor weather stations.

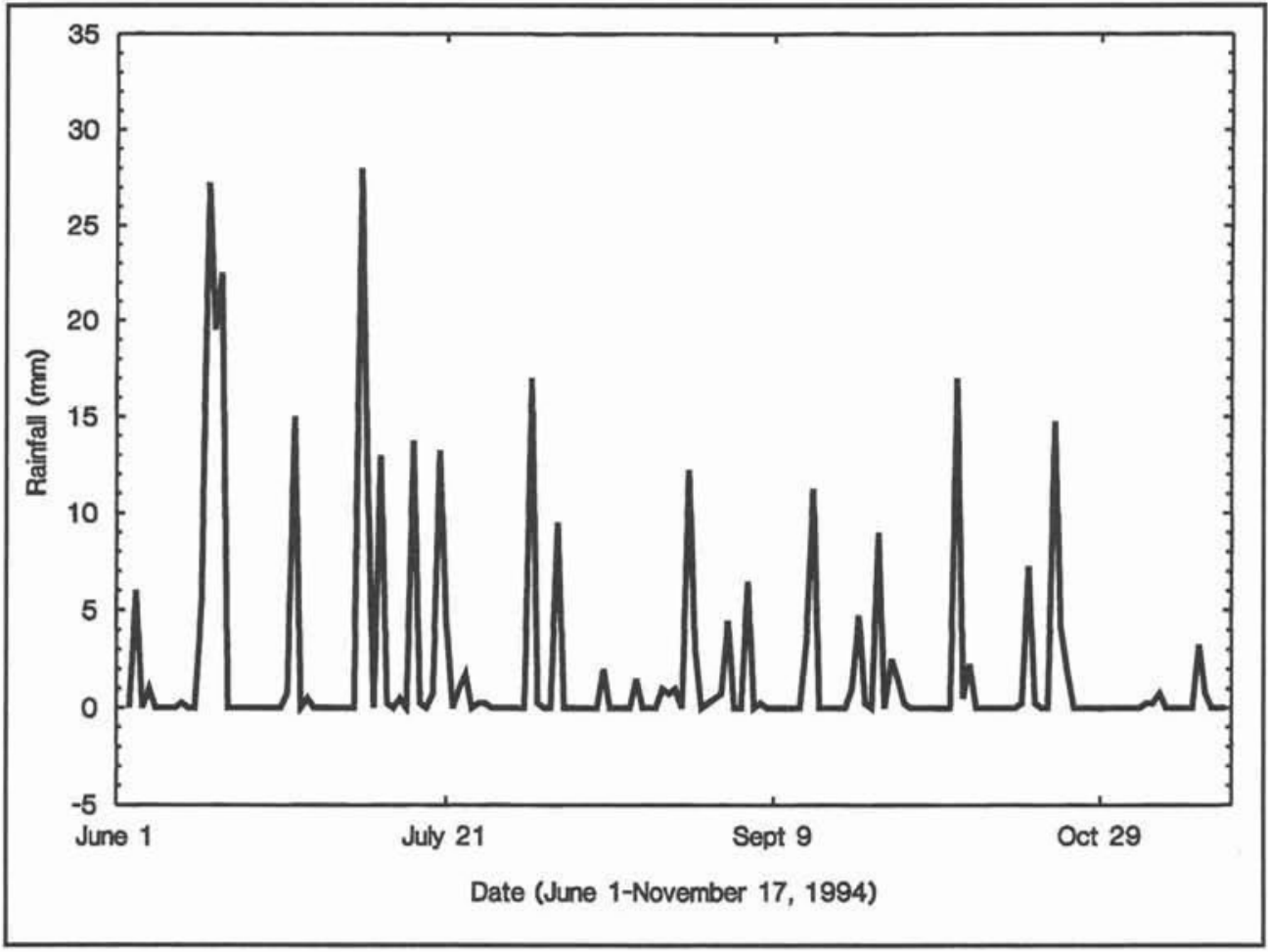

Fig. 5. Precipitation events during the first growing season after alternative conifer release treatments. Data presented are from $\mathrm{Li}$-Cor weather stations. 

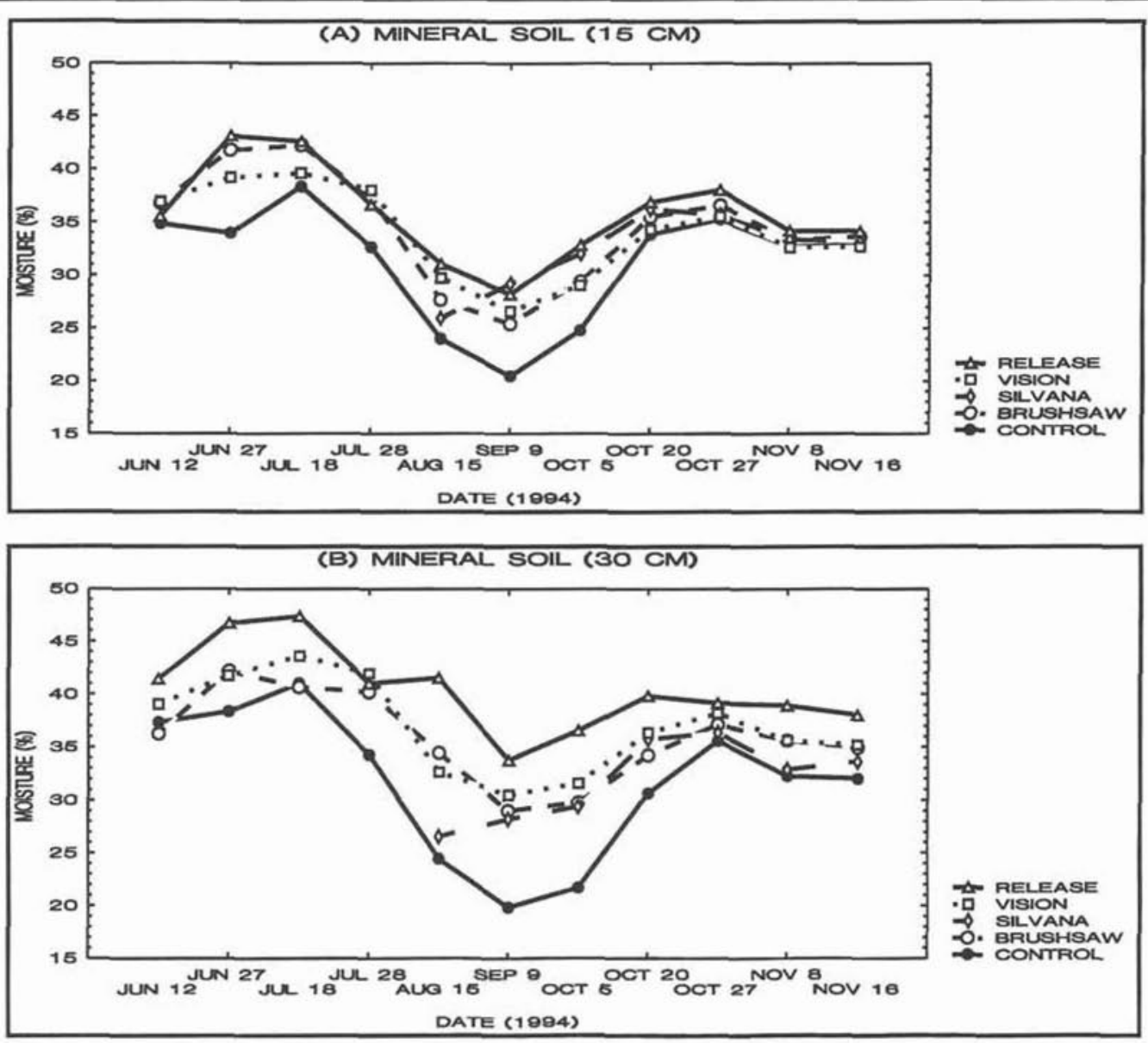

Fig. 6. Seasonal soil moisture (\%) differences at 15 and $30 \mathrm{~cm}$ depth during the first growing season after alternative conifer release treatments. Data presented were obtained from buried thermister/resistance soil cells (ELE International, Soiltest Products Division).

those observed beneath vegetation growing on the control treatment.

The increased solar radiation received on the forest floor likely resulted in higher forest floor temperatures in early summer (not measured), and sustained higher daily mean temperatures on the forest floor for the Vision ${ }^{B}$ treatment. Higher forest floor temperatures resulted in soil warming of the duff $(5 \mathrm{~cm})$ in early summer and of the mineral soil $(15$ and $30 \mathrm{~cm})$ throughout the summer of 1994 (i.e. first growing season after the treatments). Soil temperatures were higher following all the conifer release treatments, and generally highest following the Vision ${ }^{\circledR}$ treatment. The Vision ${ }^{\circledR}$ treatment caused the greatest reduction in vegetation cover, and therefore soils on these plots received the most soil irradiation and had the highest mean daily forest floor temperatures in August.

Like forest floor temperatures, $\mathrm{RH}$ near the forest floor was affected by treatment type. In August, $\mathrm{RH}$ near the forest floor remained lowest (warmest temperatures) for the Vision ${ }^{8}$ treatment, intermediate for the brush saw treatment (intermediate temperatures), and highest for the control treatment (coolest temperatures). In August, the absence of vegetation at $2 \mathrm{~m}$ above the forest floor resulted in lower mean daily $\mathrm{RH}$ for the Vision ${ }^{\circledR}$ and brush saw treatments, whereas vegetation in excess of $2 \mathrm{~m}$ height for the control treatment resulted in higher mean daily $\mathrm{RH}$ levels. Although fewer $\mathrm{RH}$ measurements occurred in early summer, a similar trend for RH among treatments probably existed at $2 \mathrm{~m}$ above the forest floor in early June. Since regrowth of vegetation on the brush saw treatment had not occurred in early June, RH near the forest floor for this treatment probably followed a pattern similar to PAR, possibly more like the Vision ${ }^{\circledR}$ treatment in early June. RH near the forest floor for brush saw plots probably increased gradually as vegetation resprouted and grew.

Most major rains occurred early in the summer when forest floor temperatures were highest. During this period, soil moisture levels $(15$ and $30 \mathrm{~cm}$ ) peaked, with the highest levels in the conifer release treatments, especially for the Vision ${ }^{\circledR}$ and Release ${ }^{\circledR}$ treatments. These higher soil moisture levels likely reflect the reduced on-site transpiration by vegetation. Vision ${ }^{\circledR}$ which provided the best first growing season control of herbaceous and woody vegetation (Bell et al. 1997a,b) had soil moisture levels consistently higher than controls. Release ${ }^{\circledR}$ did not seem to control non-crop vegetation during the first posttreatment growing season as effectively as Vision ${ }^{\circledR}$ (Bell et al. $1997 \mathrm{a}, \mathrm{b})$, but contributed as much as Vision ${ }^{\circledR}$ to moisture availability and likely the availability of associated nutrients. Although site evapotranspiration was temporarily reduced by both brush saw and Silvana Selective treatments, this reduction was less because roots of cut vegetation remained intact. Through time, site evapotranspiration for these two treatments should increase as resprouting becomes more vigorous, accompanied by a decline in soil moisture levels. 
Warmer soil temperatures combined with wetter soils should result in higher rates of nitrogen mineralization (Powers 1990), setting the stage for additional nutrient availability, enhanced nutrient uptake, and improved seedling nutrition (Nambiar and Sands 1993). Powers (1990) studied nitrogen mineralization along an altitudinal gradient, and reported that $\mathrm{N}$ release increased with increasing moisture and temperature. The highest soil temperatures and moisture levels were observed on Vision ${ }^{\circledR}$ treated plots, which had the lowest vegetation cover (Bell et al. 1997a).

Cutting and herbicide treatments reduced competing vegetation and improved microclimatic conditions for young spruce. Vision ${ }^{\circledR}$ caused the greatest reduction in vegetation cover and therefore the greatest improvements to microclimatic conditions for young spruce.

\section{Acknowledgements}

Funding for this research was received from Ontario's Vegetation Management Alternatives Program (VMAP) via the Agriculture Research Institute of Ontario (ARIO), the federal government Green Plan Forestry Practices initiative, the Canadian Forest Service, and the University of Guelph.

\section{References}

Bell, F.W., R.A. Lautenschlager, R.G. Wagner, D.G. Pitt, J.W. Hawkins and K.R. Ride. 1997a. Motor-manual, mechanical, and herbicide release affect early successional vegetation in northwestern Ontario. For. Chron. 73: 61-68.

Bell, F.W., K.R. Ride, M.L. St.-Amour and M. Ryans. 1997b. Productivity, cost, efficacy and cost effectiveness of motor-manual, mechanical, and herbicide release of boreal spruce plantations. For. Chron. 73: 39-46.

Bosch, J.M. and J.D. Hewlett. 1982. A review of catchment experiments to determine the effects of vegetation changes on water yield and evapotranspiration. J. Hydrol. 55: 3-23.

Brand, D.G. and P.S. Janas. 1988. Growth and acclimation of planted white pine and white spruce seedlings in response to environmental conditions. Can. J. For. Res. 18: 320-329.

Burger, J.A. and W.L. Pritchett. 1984. Effects of clearfelling and site preparation on nitrogen mineralization in a southern pine stand. Soil Sci. Soc. Am. J. 48: 1432-1437.

Eastman, P.A.K. and E.L.Camm. 1995. Regulation of photosynthesis in interior spruce during water stress: changes in gas exchange and chlorophyll fluorescence. Tree Physiol. 15: 229-235.

Harvey, A.E., M.F. Jurgensen, M.J. Larsen and J.A. Schlieter. 1986. Distribution of active ectomycorhizal short roots in forest soils of the inland northeast: effects of site and disturbance. USDA Forest Service Research Paper INT-374.

Hawkins, J.W., M.W. Lankester, R.A. Lautenschlager and F.W. Bell. 1997. Effects of alternative conifer release treatments on terrestrial gastropods in northwestern Ontario. For. Chron. 73: 91-98. Karakatsoulis, J., J.P. Kimmins and R.E. Bigley. 1989. Comparison of the effects of chemical (glyphosate) and manual conifer release on conifer seedlings physiology and growth on Vedder Mountain, British Columbia. Pp. 168-188. In: Proceedings of the Carnation Creek Herbicide Workshop. P.E. Reynolds (ed.). FRDA Report 063, B.C. Ministry of Forests, Victoria, BC. 349 p.

Kochenderfer, J.N. and G.W. Wendel. 1983. Plant succession and hydrologic recovery on a deforested and herbicided watershed. For. Sci. 29: 545-558.

Lautenschlager, R.A. 1993. Response of wildlife to forest herbicide applications in northern coniferous ecosystems. Can. J. For. Res. 23: 2286-2299.

Lautenschlager, R.A., F.W. Bell and R.G. Wagner. 1997a. Alternative conifer release treatments affect small mammals in northwestern Ontario. For. Chron. 73: 99-106.
Lautenschlager, R.A., F.W. Bell, R.G. Wagner, and J.A. Winters. 1997b. The Fallingsnow Ecosystem Project: Comparing conifer release alternatives in northwestern Ontario. For. Chron. 73: 35-38. Lieffers, V.J., A.G. Mugasha and S.E. MacDonald. 1993. Ecophysiology of shade needles of Picea glauca saplings in relation to removal of competing hardwoods and degreee of prior shading. Tree Physiol. 12: 271-280.

Matson, P.A. and P.M. Vitousek. 1981. Nitrogen mineralization and nitrification potentials following clearcutting in the Hoosier National Forest, Indiana. For. Sci. 27: 781-791.

Meredith, M.P. and S.V. Stehman. 1991. Repeated measures experiments in forestry: focus on analysis of response curves. Can. J. For. Res. 21: 957-965.

Mitchell, J.L. and M.L. St-Amour. 1995. Silvana Selective/Ford Versatile cleaning machine working in western Canada: An evaluation. For. Eng. Res. Inst. Can. (FERIC), Pointe-Claire, Que, Silv. Tech. Note TN-225. 10 p.

Nambiar, E.K.S. and R. Sands. 1993. Competition for water and nutrients in forests. Can. J. For. Res. 23: 1955-1968.

Newton, M., E.C. Cole, M.L. McCormack, Jr.and D.E. White. 1992. Young spruce-fir forests released by herbicides II. Conifer response to residual hardwoods and overstocking. North. J. Appl. For. 9: 130-135. Powers, R.F. 1990. Nitrogen mineralization along an altitudinal gradient: interactions of soil temperature, moisture, and substrate quality. For. Ecol. Mgmt. 30: 19-29.

Radosevich, S.R. and K. Osteryoung. 1987. Principles governing plant-environment interactions. Pp. 105-156. In: Vegetation management for conifer production. J.D. Walstad and P.J. Kuch (eds.). John Wiley \& Sons, New York. 523 p.

Rowe, J.S. 1972. Forest regions of Canada. Publication No. 1300, Dept. of Environ., Can. For. Serv. Ottawa, ON. 172 p.

Ruehle, J.L. 1982. Field performance of container-grown loblolly pine seedlings with specific ectomycorryhizae on a reforestation site in South Carolina. South. J. Appl. For. 6: 30-33.

Simpson, J.A., A.M. Gordon, P.E. Reynolds, R.A. Lautenschlager, F.W. Bell, D.A. Gresch and D.A. Buckley. 1997. Influence of alternative conifer release treatments on soil nutrient movement. For. Chron. 73: 69-73.

Stanford, G. and E. Epstein. 1974. Nitrogen mineralization-water relations in soils. Soil Sci. Soc. Amer. Proc. 38: 103-107.

Stone, E. 1973. The impact of timber harvest on soil and water. pp. 427-467 In: Report of the President's Advisory Panel on timber and the environment. Government Printing Office, Washington, DC.

Thompson, D.G., D.G. Pitt, B. Staznik, N.J. Payne, D. Jaipersaid, R.A. Lautenschlager and F.W. Bell. 1997. On-target deposit and vertical distribution of aerially released herbicides. For. Chron. 73: 47-59.

Van Cleve, K., L.A. Viereck and G.M. Marion. 1993a. Introduction and overview of a study dealing with the role of salt-affected soils in primary succession on the Tanana River floodplain, interior Alaska. Can. J. For. Res. 23: 879-888.

Van Cleve, K., J. Yarie, R. Erickson and C.T. Dyrness. 1993b. Nitrogen mineralization and nitrification in successional ecosystems on the Tanana River floodplain, interior Alaska. Can. J. For. Res. 23: 970-978.

Vare, H. 1989. The mycorrhizal condition of weakened Scots pine saplings grown on ploughed sites in northern Finland. Can. J. For. Res. 19: 341-346.

Vitousek, P.M. and W.A. Reiners. 1975. Ecosystem succession and nutrient retention: a hypothesis. BioScience 25: 376-381.

Walstad, J.D. and P.J. Kuch. 1987. Forest Vegetation Management for Conifer Production. John Wiley and Sons, New York. 523 p.

Wood, J.E. and F.W. von Althen. 1993. Establishment of white spruce and black spruce in boreal Ontario: effects of chemical site preparation and post-planting weed control. For. Chron. 69(5): 554-560. Woodcock, J.M., R.A. Lautenschlager, F.W. Bell, and J.P. Ryder. 1997. Conifer release alternatives affect songbird population in northwestern Ontario. For. Chron. 73: 107-112. 